\title{
Recombinant Platelet Factor 4
}

National Cancer Institute

\section{Source}

National Cancer Institute. Recombinant Platelet Factor 4. NCI Thesaurus. Code C2251.

A recombinant form of the endogenous chemokine platelet factor 4 with potential antiangiogenesis and antineoplastic activities. As a heparin-binding tetramer, recombinant platelet factor 4 inhibits growth factor-stimulated endothelial cell proliferation, migration, and angiogenesis; it has been shown that this agent inhibits fibroblast growth factor 2 (FGF2) ang iog enic activity downstream from the FGF2 receptor. Its activity is antagonized by heparin. Recombinant platelet factor 4 may also directly inhibit the proliferation of some tumor cell types. 